\title{
Diagnosis of the bovine leukaemia virus infection in Polish Holstein-Friesian cows and comparison of their milk productivity
}

\author{
Received March 11, 2011 \\ Accepted September 19, 2012
}

Małgorzata Szewczuk, Sławomir Zych, Sylwia Katafiasz

The West Pomeranian University of Technology, Department of Ruminant Science, Laboratory of Molecular Cytogenetics, Szczecin, Poland

\begin{abstract}
Economic losses due to the bovine leukaemia virus infection can come from reduced milk production. The aim of this study was to evaluate molecular multiplex Polymerase Chain Reaction (multiplex PCR) test as an alternative for serologic Enzyme-linked Immunosorbent Assay (ELISA) method in diagnosing bovine leukaemia virus infections and found possible differences in milk yield in seronegative and seropositive cows. The study involved two groups of Polish Holstein-Friesian var. black and white cows (a total of 147 individuals). Animals were grouped according to their serological response to the bovine leukaemia virus antigen: control group of 71 healthy cows and second group of 76 naturally infected animals. Both multiplex PCR and ELISA proved to be very sensitive methods with sensitivity up to $100 \%$ and $97.4 \%$, respectively. Negative effect of bovine leukaemia virus on milk yield was observed. Leucosis-free cows achieved higher milk yield $(+322.9 \mathrm{~kg} ; P \leq 0.01)$, protein yield $(+5.2 \mathrm{~kg}$, $P \leq 0.05)$, and better milk yield after calculation into daily milk yield corrected for fat $(+106.6 \mathrm{~kg}, P \leq 0.05)$ in comparison to seropositive cows. In infected cows a significantly higher $(P \leq 0.01)$ fat content $(4.1 \%)$ was recorded. Because ELISA test does not provide information of the infection at an early stage and is not sensitive enough to detect every infected animal, a twostep protocol allows for elimination of seropositive animals and restriction of their introduction into herds in Europe.
\end{abstract}

Enzootic bovine leucosis, multiplex PCR, dairy cows, milk traits

Enzootic bovine leucosis (EBL) is an important disease in many regions of Europe. In Poland the disease appears usually in large dairy herds in northern and north-east regions, within a belt surrounding the Baltic Sea. Enzootic bovine leucosis is caused by the bovine leukaemia virus (BLV), which is an oncogenic virus belonging to Deltaretrovirus genus (Fauquet et al. 2005). The genetic material of the virus is composed of two identical single-stranded RNA molecules, which are transcribed into the DNA in infected cells and then integrated into the bovine genome as a provirus (Shigeru et al. 1998). Domestic cattle are natural hosts for BLV.

The major target cell of the virus is usually the B lymphocyte. However, it can be also found in $\mathrm{T}$ lymphocytes, monocytes, macrophages, granulocytes and in the cells of numerous organs and tissues (Heeney et al. 1992). The virus has also been found in mammary epithelial cells (Buehring et al. 1994).

Various indirect and direct methods have been used for detection of BLV-infected carriers including haematological and syncytial tests, Western Blot, Agar Gel Immunodiffusion (AGID), Enzyme-linked Immunosorbent Assay (ELISA), and Polymerase Chain Reaction (PCR) (Martin et al. 2001).

Because BLV infection affects directly the immune system, its impact on herd health and economy could be more extensive than direct loss from death of a single individual following lymphomas. The milk yield is an important economic and health factor closely connected with the health status of dairy cows that is expressed by higher susceptibility to infectious diseases (i.e. mastitis, dermatophytosis), their reproductive performance,

Address for correspondence:

Malgorzata Szewczuk, $\mathrm{PhD}$

Laboratory of Molecular Cytogenetics

Department of Ruminant Science

The West Pomeranian University of Technology

Judyma 10, 71-460 Szczecin, Poland

Phone: +48914496802

E-mail: malgorzata.szewczuk@zut.edu.pl

http://actavet.vfu.cz/ 
longevity and milk composition and properties (Trainin and Brenner 2005; Janu et al. 2007; Hanuš et al. 2007).

The aim of this study was to evaluate a multiplex PCR test as an alternative of ELISA for detection of bovine leukaemia virus in blood samples obtained from dairy cows and to find differences between healthy and BLV-infected cows in milk yield.

\begin{abstract}
Materials and Methods
Animals

A total of 147 pure breed Polish Holstein-Friesian cows being in the same lactation, similar age of life and kept in one herd (Kuyavia and Pomerania province) were used in this study. In January 2009, materials for biochemical (serum) as well as genetic (whole blood) tests were collected. Blood samples without anticoagulant were allowed to clot at room temperature and centrifuged at $1200 \times \mathrm{g}$ for $15 \mathrm{~min}$ within less than $12 \mathrm{~h}$ after collection. Serum was stored at $-20^{\circ} \mathrm{C}$ until analysis. Blood samples with anticoagulant were stored at $4{ }^{\circ} \mathrm{C}$ for $24 \mathrm{~h}$ until isolation of DNA. For DNA isolation, MasterPure ${ }^{\mathrm{TM}}$ Genomic DNA Purification Kit (Epicentre Technologies, USA) was used according to the manufacturer isolation procedure. DNA was stored at $-20{ }^{\circ} \mathrm{C}$ until analysis. Above mentioned material was intended for use to determine selected biochemical blood indicators of clinically healthy cows as well as for association study between various gene polymorphisms and milk production traits (another study).

In March 2009, as the result of obligatory herd screening using ELISA tests (IDEXX Laboratories, Westbrook, USA) carried out at the Institute of Veterinary Hygiene (IVH), presence of antibodies to bovine leukaemia virus was detected. Based on their results, cows were divided into two groups, BLV seropositive $(\mathrm{n}=76)$ and BLV free $(\mathrm{n}=71)$. Previously planned research was suspended. According to national regulations, the whole herd was designed for liquidation in April 2009.
\end{abstract}

Serology confirmation

Twenty four previously frozen serum samples (selected after results of IVH screening, supposed to be BLV positive $(n=12)$ and BLV negative $(n=12)$ were analyzed for the confirmation of presence of anti-BLV antibodies in analyzed herd and to obtain further control for PCR. The Bovine Leukaemia Virus Antibody ELISA Test Kit (IDEXX HerdChek Anti-BLV Screening; IDEXX Laboratories, Westbrook, USA) was used according to the manufacturer's recommendation. The positive test result was set at the cut-off point of serum to positive $(\mathrm{S} / \mathrm{P})$ ratio greater than 0.5 . A verification microtitre plate (IDEXX HerdChek Anti-BLV Verification; IDEXX Laboratories, Westbrook, USA) was included to confirm positive results.

\title{
PCR examination
}

The presence of proviral DNA in lymphocytes was identified using Polymerase Chain Reaction and its variant multiplex PCR. A total of 147 previously frozen DNA samples were examined. Two sequences of DNA were amplified. The first one is located within the $G A G$ gene of the provirus (Reichert and Stec 1999) and the second one is a sequence of the 5 ' flanking region ( $\mathrm{P} 1$ promoter) of the bovine insulin-like growth factor 1 (IGF1) gene that was used as a PCR internal control (Barendse et al. 2000).

The $20 \mu \mathrm{l}$ (PCR) or $40 \mu \mathrm{l}$ (multiplex PCR) reaction mixture contained $10 \mathrm{pmol}$ of each appropriate primer, 85 ng of genomic DNA, $2 \mathrm{mM}$ dNTP mix, and 0.5 unit of Taq polymerase with buffer and $\mathrm{MgCl}_{2}\left(\mathrm{MBI}^{\mathrm{Fermentas}}{ }^{\mathrm{TM}}\right.$, ABO Poland). After the initial denaturation at $94{ }^{\circ} \mathrm{C}$ for $5 \mathrm{~min}$, amplification was run through 33 cycles of $94{ }^{\circ} \mathrm{C}$ for $50 \mathrm{~s}, 62{ }^{\circ} \mathrm{C}$ for $55 \mathrm{~s}$, and $72{ }^{\circ} \mathrm{C}$ for $50 \mathrm{~s}$, and was followed by a $7 \mathrm{~min}$ extension period at $72{ }^{\circ} \mathrm{C}$ in a Tpersonal DNA thermal cycler (Biometra, Germany). In a preliminary study based on the results of our ELISA confirmation $(n=24)$, one positive and one negative DNA control samples were established. For estimation of possible PCR detection limit, one sample of DNA obtained from confirmed BLV seropositive cow was tenfold diluted and then a PCR was ran to verify amount of DNA that could be successfully amplified. However, even in this case visible amplification was obtained.

Then each subsequent PCR was always run with positive and negative control samples as an internal control of reaction to avoid false-negative and false-positive results. In order to check the results, $10 \mu \mathrm{l}$ of the reaction product (PCR or multiplex PCR) was resolved in $2 \%$ agarose gel (Basica Prona Agarose ${ }^{\mathrm{TM}}$, ABO Poland) stained with ethidium bromide and analyzed under UV light $(312 \mathrm{~nm})$ in transilluminator (Vilber Lourmat ${ }^{\mathrm{TM}}$, France). The length of the obtained DNA sequences was compared to standard DNA marker pUC19/MspI (Fermentas ${ }^{\mathrm{TM}}$, ABO Poland). The PCR products were visualized and recorded. If the product of $I G F 1$ gene was indistinctive or absent, the PCR was repeated. Specificity of the amplified products was confirmed by direct sequencing of three samples ( $G A G$ gene; IBB PAN, Warsaw) or by restriction analysis (IGF1 gene) (data not shown).

After examination, all biological materials (serum, template DNA) were utilized according to the national regulation of medical waste management.

Association study

Data for 305-day milk production of all the cows under study were analyzed. Analysis of milk yield was performed on the basis of data from milk recording using A4 method. The method involving twice-daily milking performed once a month (at least 11 tests per year) with determination of milk yield, amount of fat and protein (in $\mathrm{kg}$ ) and percentage of fat and protein in milk. We also determined the following traits: difference between fat 
and protein content $(\mathrm{RTB} \%$ ), ratio of protein to fat content (SBT) and daily milk yield corrected for fat (FCM). In order to compare the collected results a standard milk yield with $4 \%$ fat content was defined according to the Burgstaller's formula (1985). Data about milk yield were gained from farm breeding documentation, i.e. tabulations (T1, T2), heifers - cows registration papers and barn diary. The cows were bred in a confinement system (tie-stall system). Although the herd seroprevalence was high, clinical signs or lymphosarcoma were uncommon.

\section{Statistics}

Statistical analysis was performed using Statistica 9.0 PL based on General Linear Model (GLM): $\mathrm{Y}_{\mathrm{ijklm}}=\mu+$ $\mathrm{G}_{\mathrm{i}}+\mathrm{L}_{\mathrm{i}}+\mathrm{S}_{\mathrm{k}}+\mathrm{CS}_{1}+\mathrm{a}_{\mathrm{m}}\left(\mathrm{x}_{\mathrm{m}}-\mathrm{x}\right)+\mathrm{e}_{\mathrm{ijklm}}$, where: $\mathrm{Y}_{\mathrm{ijklm}}$ - analyzed trait, $\mu$ - overall mean, $\mathrm{G}_{\mathrm{i}}-$ fixed effect of group $\left(i=1,2\right.$; infected or healthy cows), $L_{j}$ - fixed effect of lactation $(j=1,2), S_{k}$ - random effect of sire $(k=1, \ldots 87)$, $\mathrm{CS}_{1}$ - fixed effect of calving season $(1=1,2$; spring/summer; autumn/winter $), \mathrm{a}_{\mathrm{m}}$ - linear regression coefficient of age at first calving, $\mathrm{x}_{\mathrm{m}}$ - age at first calving, $\mathrm{x}$ - mean age at first calving, $\mathrm{e}_{\mathrm{ijklm}}$ - random error.

\section{Results}

\section{Results of ELISA}

Among the 147 cows examined in routine screening test carried out in IVH, the presence of antibody to BLV was identified in $51.7 \%$ of animals $(n=76$; Table 1$)$. In the present study carried out on selected negative $(n=12)$ and positive $(n=12)$ samples, the OD value ranged from 0.078 to 0.239 and 0.535 to 2.303 , respectively. One sample $(\mathrm{OD}=0.535 ; \mathrm{S} / \mathrm{P}=0.715)$ was classified as weak positive. A verification microtitre plate confirmed these results.

\section{Results of multiplex PCR}

To detect presence of provirus DNA in blood samples of infected cattle, the PCR protocol for amplification of partial $G A G$ gene with internal control of the PCR reaction was developed. In the case of the twelve chosen BLV $(+)$ cows, the PCR amplification resulted in $364 \mathrm{bp}$ and $289 \mathrm{bp}$ long DNA products for $G A G$ and $I G F 1$ genes, respectively (Plate II, Fig. 1). All seronegative samples were confirmed by a multiplex PCR (no genetic material of the provirus was found). The yield of amplification of the IGF1 gene fragment was similar in the most cases, but differences of amplification of the $G A G$ gene occasionally were observed.

\section{Differences between both methods}

Since multiplex PCR protocol was finally determined, genetic studies were extended to the whole herd $(n=147)$. Comparison of results obtained using different methods (ELISA and PCR) performed on small population did not show significant differences in detection of proviral DNA (Table 1). However, there were two negative instead of positive samples compared to the ELISA assay. We assume that this difference is due to an earlier collection of material rather than low PCR sensitivity.

In the case of one weak positive sample in the ELISA test, two bands characteristic for positive sample were observed, but fluorescence of the upper band (around $364 \mathrm{bp}$ ) was less intensive compared to other positive samples (Plate II, Fig. 1, lane 5). It might indicate a smaller amount of template in the isolated DNA and thus a smaller percentage of infected

Table 1. Seroprevalence of bovine leukaemia virus infection and direct provirus detection in heifers using ELISA and multiplex PCR.

\begin{tabular}{lccccccc}
\hline Test result & \multicolumn{2}{c}{ ELISA (source: IVH) } & \multicolumn{3}{c}{ ELISA (present study) } & \multicolumn{3}{c}{ Multiplex PCR (present study) } \\
& $\mathrm{n}$ & $\%$ & $\mathrm{n}$ & $\%$ & $\mathrm{~S} / \mathrm{P}$ & $\mathrm{n}$ & $\%$ \\
\hline Negative & 71 & 48.3 & 12 & 50 & 0.123 & 73 & 49.7 \\
Positive & 76 & 51.7 & 12 & 50 & 2.620 & 74 & 50.3 \\
Total & 147 & & 24 & & & & \\
Sensitivity & $100 \%$ & & $100 \%$ & & & & \\
\end{tabular}

$\mathrm{n}$ - number of heifers, S/P - average S/P ratio, IVH - Institute of Veterinary Hygiene 
Table 2. Means and their standard errors for milk production traits in seronegative and seropositive cows in regard to bovine leukaemia virus.

\begin{tabular}{lrrrr}
\hline Milk trait & \multicolumn{2}{c}{$\begin{array}{c}\text { Seronegative cows } \\
(\mathrm{n}=71)\end{array}$} & \multicolumn{2}{c}{$\begin{array}{c}\text { Seropositive cows } \\
(\mathrm{n}=76)\end{array}$} \\
& \multicolumn{1}{c}{$\mathrm{x}$} & $\mathrm{SE}$ & $\mathrm{X}$ & $\mathrm{SE}$ \\
\hline Milk yield (kg) & $7802.5^{* *}$ & 150.5 & $7479.6^{* *}$ & 131.2 \\
Fat $(\mathrm{kg})$ & 302.6 & 6.24 & 304.1 & 5.64 \\
Fat (\%) & $3.88^{* *}$ & 0.04 & $4.07 * *$ & 0.04 \\
Protein (kg) & $247.4 *$ & 4.68 & $242.2 *$ & 4.36 \\
Protein (\%) & 3.18 & 0.03 & 3.24 & 0.03 \\
RTB (\%) & 0.70 & 0.036 & 0.83 & 0.03 \\
SBT & 0.82 & 0.008 & 078 & 0.007 \\
FCM & $7659.4 *$ & 14.8 & $7552.8 *$ & 133.0 \\
\hline
\end{tabular}

Means within rows bearing the same superscripts differ significantly at: **P $\leq 0.01, * P \leq 0.05$

$\mathrm{x}$ - mean, SE - standard error, RTB - difference between fat and protein content, SBT - ratio of protein to fat content, FCM - daily milk yield corrected for fat

lymphocytes. Nevertheless, this sample should be considered as positive, despite initial doubts after running the ELISA test.

Impact on productivity

Presence of proviral DNA at the early stage of lactation may suggest an indirect effect on biosynthesis of milk components in the mammary glands. Therefore, the association between provirus presence and milk production traits were examined. The results are summarized in Table 2.

Milk yield was higher in healthy cows compared to seropositive cows. The difference of $+322.9 \mathrm{~kg}(+4.3 \%)$ was significant $(P \leq 0.01)$. Milk yield after calculation into FCM was also higher in healthy $(+106 \mathrm{~kg})$ compared to infected animals $(P \leq 0.05)$. Milk from infected cows had higher fat $(+0.19 \% ; P \leq 0.01)$ and protein $(+0.06 \%)$ content in comparison to healthy cows. Fat yield was also higher in infected cows. However, the difference in fat yield $(+1.5 \mathrm{~kg})$ was not significant. Significantly higher $(P \leq 0.05)$ protein yield (+5.2 kg) of BLV(-) cows in comparison with infected cows was also recorded. Two traits, RTB\% and SBT ratios, were not differ significantly between two groups.

\section{Discussion}

Serologic methods involving antibody detection are rapid, inexpensive and easy to interpret. However, antibodies may not be produced until 14 weeks after infection. Thus, using ELISA may lead to leaving some unidentified virus carriers in the herd. In addition, there could be more dubious samples. Before deciding to eliminate an animal from the herd, a PCR test should always be performed.

Early stages of BLV infection with no anti-BLV antibodies production, chronic BLV infections without or with low anti-BLV antibody levels as well as lower AGID or ELISA sensitivity are factors favouring the PCR screening results. The PCR test is very advantageous for its sensitivity and specificity. In the present study, both multiplex PCR and ELISA proved to be very sensitive methods with sensitivity up to $100 \%$ and $97.4 \%$, respectively. However, it is not possible to compare directly the two methods due to a different period of time between our and IVH sampling. Rułka et al. (2001) claimed that PCR sensitivity is up to $100 \%$ and ELISA up to $95 \%$. Reichert and Stec (1999) estimated specificity of selected primers at the level of $90.4 \%$. Simultaneous amplification 
with two or more primer pairs (for example flanking $G A G$ and $E N V$ gene) could increase the sensitivity of the PCR assay for detection of BLV infection.

The PCR test is particularly useful in calves during the few first months of their lives, when their blood contains antibodies from colostrum of infected cows and the synthesis of own anti-BLV immunoglobulines is still at a low level. It is known that calves receiving colostrum from infected cows may remain seropositive to BLV until the age of 6 months (Burridge et al. 1981). Lassauzet et al. (1989) found that feeding calves on colostrum from infected cows on the one hand provides BLV antibodies protecting the animals from alimentary infection, but on the other hand such colostrum contains B-lymphocytes which may be a source of BLV infection.

The effect of subclinical BLV infection on milk production has been studied without definitive conclusions. Generally, as in the present study, milk production in non-infected animals was higher than in BLV infected cows but no significant associations were detected. Effects of BLV infection with persistent lymphocytosis (PL) on milk yields were also studied. Summary of the published reports concerning BLV infection in association to infectious disease, productivity, reproductivity and culling rate is widely described by Trainin and Brenner (2005). In a study conducted by Motton and Buehring (2003), the effect of BLV was examined at a cellular rather than herd level. This study has demonstrated that BLV can have a cellular effect on mammary epithelial cells by inhibiting their ability to produce casein in vitro and this may be through an inhibition of cell differentiation.

In summary, both tests are very sensitive methods. Considering the time and cost of the procedures, ELISA appears to be useful for the screening of large-scale herds and PCR is recommended when individual seropositive animals were found. In leucosis-free herds, newly purchased animals should be genetically tested to rule out the presence of BLV provirus in lymphocytes despite negative results of ELISA test. Use of this method to diagnose bovine leucosis ensures elimination of latent infections and eradication of the disease on farms. Our results suggest a negative impact of BLV on the milk yield. Because of polygenic control of milk synthesis in the mammary gland, the relationship may be a direct one, or may be related to unmeasured variables associated with both milk production and the BLV status, in particular to impaired health of animals. It seems purposeful to conduct additional research on the possibility of using multiplex PCR as an alternative for ELISA assay in diagnosing enzootic bovine leukaemia virus infection.

\section{References}

Barendse W, Armitage SM, Aleyasin A, Womack JE 2000: Differences between the radiation hybrid and genetic linkage maps of bovine chromosome 5 resolved with a quasi-phylogenetic method of analysis. Mamm Genome 11: $369-372$

Buehring G, Kramme P, Schultz R 1994: Evidence for bovine leukemia virus in mammary epithelial cells of infected cows. Lab Invest 71: 359-365

Burgstaller G 1985: Feeding of cow in practice. (In Polish) PWRiL, Warsaw, 56p.

Burridge MJ 1981: The zoonotic potential of bovine leukemia virus. Vet Res Commun 5: 117-126

Fauquet CM, Mayo MA, Maniloff J, Desselberger U, Ball LA 2005: Virus Taxonomy, VIII ${ }^{\text {th }}$ Report of the ICTV. Elsevier/Academic Press, London: 12-13

Hanuš O, Frelich J, Janu L, Macek A, Zajíčková I, Genčurová V, Jedelská R 2007: Impact of different milk yields of cows on milk quality in Bohemian Spotted cattle. Acta Vet Brno 76: 563-571

Heeney J, Valli P, Jacobs R, Valli V 1992: Evidence for bovine leukemia virus infection of peripheral blood monocytes and limited antigen expression in bovine lymphoid tissue. Lab Invest 66: 608-617

Janu L, Hanuš O, Frelich J, Macek A, Zajíčková I, Genčurová V, Jedelská R 2007: Influences of different milk yields of Holstein cows on milk quality indicators in the Czech Republic. Acta Vet Brno 76: 553-561

Lassauzet ML, Johnson WO, Thurmond MC, Stevens F 1989: Protection of colostral antibodies against bovine leukemia virus infection in calves on a California Dairy. Can J Vet Res 53: 424-430

Martin D, Arjona A, Soto I, Barquero N, Viana M, Gómez-Lucía E 2001: Comparative study of PCR as a direct assay and ELISA and AGID as indirect assays for the detection of Bovine Leukaemia Virus. J Vet Med, Series B, 48: 97-106 
Motton DD, Buehring GC 2003: Bovine leukemia virus alters growth properties and casein synthesis in mammary epithelial cells. J Dairy Sci 86: 2826-2838

Reichert M, Stec J 1999: Simultaneous use of two primer pairs increases the efficiency of polymerase chain reaction assay in the diagnosis of bovine leukemia virus infection. J Vet Diagn Invest 11: 543-547

Rułka J, Kubiś P, Dereń W, Buzała E 2001: The presence of BLV in blood and milk of infected cattle. (In Polish) Med Weter 57: 574-577

Shigeru T, Ikawa Y, Aida Y 1998: Complete Bovine Leukemia Virus (BLV). Provirus is conserved in BLVinfected cattle throughout the course of B-cell lymphosarcoma development. J Virol 72: 7569-7576

Trainin Z, Brenner J 2005: The direct and indirect economic impacts of bovine leukemia virus infection on dairy cattle (Review). Isr J Vet Med 60: 94-105 
Plate II

Szewczuk M. et al.: Diagnosis of the... pp. 353-358

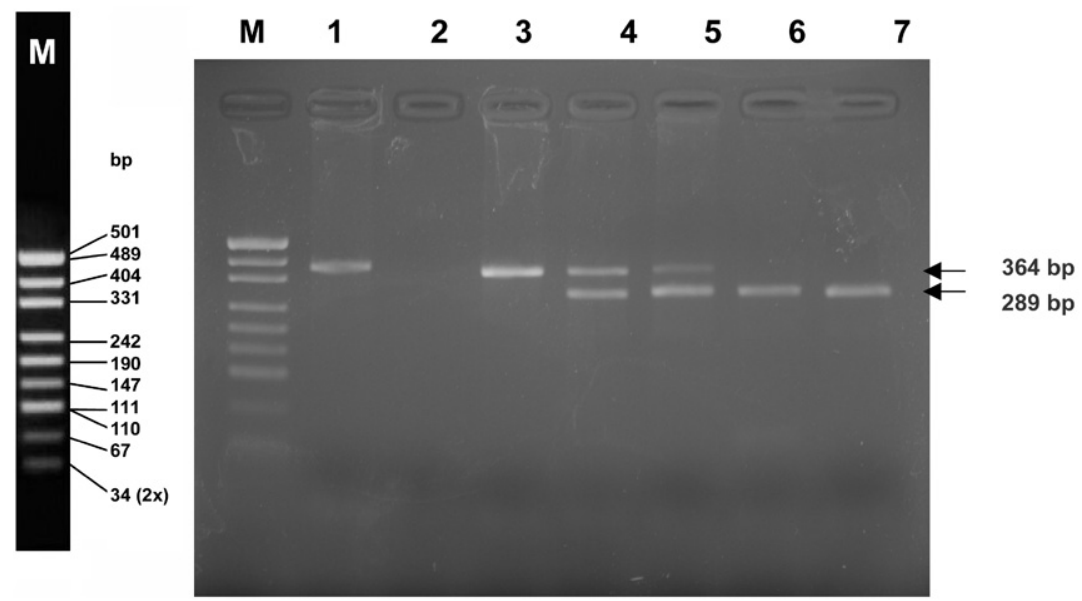

Fig. 1. A 2\% agarose gel electrophoresis of PCR products amplified by $G A G$ and $I G F 1$ primers utilized in diagnosing the bovine leukaemia virus

M - DNA standard (pUC19/MspI), Lane 1 - positive control, Lane 2 - negative control, Lane 3 strong positive sample (PCR), Lane 4 - positive sample (multiplex PCR), Lane 5 - weak positive sample (multiplex PCR), Lanes 6 and 7 - negative samples (multiplex PCR) 